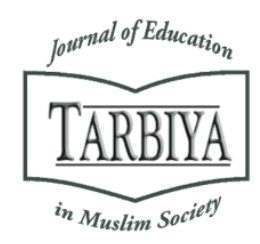

Available online at TARBIYA: Journal of Education in Muslim Society Website:

http://journal.uinjkt.ac.id/index.php/tarbiya

TARBIYA: Journal of Education in Muslim Society, 7(1), 2020, 88-101

\title{
THE EFFECT OF GOAL SETTING, SELF EFFICACY, INTEREST AND PEER SUPPORT ON SELF REGULATED LEARNING
}

\author{
Barkah Sanyoto ${ }^{1}$, Gazi Saloom ${ }^{2}$ * \\ ${ }^{1}$ Sekolah Tinggi Sandi Negara (STSN), Indonesia \\ ${ }^{2}$ Syarif Hidayatullah State Islamic University of Jakarta, Indonesia \\ E-mail: gazi@uinjkt.ac.id
}

Received: $17^{\text {th }}$ December 2019; Revised: $28^{\text {th }}$ May 2020; Accepted: $29^{\text {th }}$ June 2020

\begin{abstract}
This research aims to see whether goal setting, self-efficacy, interest and peer support altogether have impact on self-regulated learning of students of STSN. Research population is 328 students of first to fourth year of STSN, while the sample is 291 students which filtered using convenience sampling method. This is a quantitative research. Research validity is examined using Confirmatory Factor Analysis (CFA). Data is analysed using multiple regression analysis. The result shows that goal setting, self-efficacy, interest and peer support altogether have impact on self-regulated learning. Variables of intensity, course efficacy, and intrinsic orientation have significant impact on self-regulated learning. While variables of content, roommate efficacy, social efficacy, affected related valence, value related valence, intrinsic orientation, tangible, belonging, appraisal, and self-esteem are statistically not proven to have an impact on self-regulated learning. In particular, this research shows that peer support independently has no effect on self-regulated learning meanwhile previous research has shown the opposite. Further research needs to consider the utilization of operational language which culturally appropriate regarding questionnaire drafting. It is because the questionnaire with the basis of local culture will ignite appropriate response from the respondents.
\end{abstract}

Keywords: Self-regulated learning; goal setting; self-efficacy; interest; peer support

\section{Abstrak}

Penelitian ini bertujuan untuk melihat apakah penentuan tujuan, efikasi diri, minat dan dukungan teman sebaya berpengaruh bersama-sama terhadap regulasi diri mahasiswa Sekolah Tinggi Sandi Negara. Populasi penelitian adalah 328 mahasiswa STSN sedangkan sampel berjumlah 291 mahasiswa dengan menggunakan tehnik sampling convenience. Validitas alat ukur dianalisis dengan menggunakan CFA sedangkan data riset dianaisis dengan tehnik regresi berganda. Hasil penelitian menunjukkan bahwa penentuan tujuan, efikasi diri, minat dan dukungan teman sebaya secara bersama-sama berpengaruh terhadap regulasi diri mahasiswa. Secara khusus riset ini menunjukkan bahwa dukungan teman sebaya tidak berpengaruh terhadap regulasi diri mahasiswa, artinya, riset ini berbeda dengan hasil riset terdahulu yang menunjukkan bahwa dukungan teman sebaya berpengaruh terhadap regulasi diri. Penelitian lebih lanjut perlu mempertimbangkan penggunaan bahasa operasional yang sesuai dengan budaya terkait penyusunan kuesioner. Pasalnya, kuesioner yang berbasis budaya lokal akan memicu respon yang tepat dari responden.

Kata kunci: belajar regulasi diri; penentuan tujuan; efikasi diri; minat dan dukungan teman sebaya

How to Cite: Sanyoto, B., Saloom, G. (2020). The Effect of Goal Setting, Self Efficacy, Interest and Peer Support on Self Regulated Learning. TARBIYA: Journal of Education in Muslim Society, 7 (1), 88-101. doi:10.15408/tjems.v7i1.13760.

Permalink/DOI: http://dx.doi.org/10.15408/tjems.v7i1.13760 


\section{Introduction}

There are many studies conducted about learning and its methods in Indonesia (see, Rosfiani, O., Akbar, M., Neolaka, A., 2019; Ratnaningsih et. al, 2018) but rarely it focused on some concepts related self-regulated learning. Even though, self-regulated learning is pivotal concept that can be basic foundation of success in any learning particularly in higher education. Hence, studies on self-regulated learning are still needed.

One of the biggest challenges for future universities is to prepare their students for selflearning capability. From an educational point of view, self-regulated learning means having the capability to regulate one's learning process (Schunk \& Zimmerman, 2003; Zimmerman, 2002), which can be mentioned as self-regulated learning.

Self-regulated learning is the ability to be held responsible to direct and regulate the learning process (Balapumi \& A. Aitken, 2012), the ability to persist when facing learning difficulty, self-resources and time management.

Research from Allgood, Risko, Alvarez, and Fairbank (2000) mentioned that most of the students who want to continue their education to higher level are not ready to handle the learning process in university. This happens because the students cannot control their own learning process (Rosario, Mauao, Nunez, Gonzales-Pienda, Solano \& Valle, 2007), also they lack self-regulation strategy in learning., which is considered as the main factor in failure at the university (Tuckman, 2003). Students who can't learn independently will have difficulty to identify and to determine their academic goals, develop and maintain suitable learning strategy and motivation (Lieberman \& Remedios, 2007; Stewart, Stott, \& Nuttall, 2015).
Usually in college, students are given independency about when and how would they learn. But many students still find it difficult to balance time for learning, social activities, and family responsibilities. In fact, the ability and skill to manage time for learning and learning itself enables students to better adapt to academic demands and balance it better with social demands in college (Pintrich, 1995).

In contrast, freedom and independence in learning at boarding schools are different because they are influenced by education provider system and policies. Cookson et al. (2009) remarked that students who learn at boarding school have strict regulation and schedule, in the form of students' daily routine which dictates when should they wake up, sleep, eat, and participate in recreational activity, and direct how, when, and where should they finish their homework and assignments, and access to telephone and computer (Cookson, 2009; Cree, 2000; BR Lee \& Barth, 2009; Williams, 2011).

Perven and Kazmi (2011), Zirima (2012), Behaghely (2015) have different points of view about boarding school. Boarding school is seen as to make the learning atmosphere more enjoyable because there is a strategy to manage and self-control in learning, improve academic capability in supportive 24 hours' environment, extracurricular, interaction with other people, and independence fostering.

Based on interviews with students of STSN (September 2017 - May 2018), there are several ineffective learning strategy indicators in each educational level which affect the quality of student learning, such as limitation in developing learning strategies, lack of knowledge and information about assignment, inability to determine assignment characteristic, and miscalculation on time needed to finish an assignment. These happen because the students are unable to set goals, execute plan, evaluate and 
control the learning process (Bembenuty, 2011; Pintrich \& Zusho, 2002).

Research suggests several factors which support self-regulated learning, such as learning goal setting, learning attentively and concentration (interest), utilizing strategy to organize code and rehearse learned information, learning performance monitoring, effective time management, seeking help from friends or other people (peer support), confidence in their own ability (self-efficacy), have learning value, knowing factors that affect learning and anticipate outcomes, and insightful and valuable experience gained from effort (McCombs, 1989; Pintrich \& De Groot, 1990; Weinstein \& Mayer, 1986; Zimmerman, 1994).

\section{Self-regulated Learning}

Self-regulated learning is an action and process which is directed to gain information and skills involving purpose and perception, equipment needed by the students including method to organize and transform information, consequence on oneself, seeking information, practicing and utilizing memory aid devices (Zimmerman \& Martinez-Pons, 1986; Bandura, 1986; Pintrich, Cross, Kozma \& McKeachie, 1986).

Definition of student self-regulated learning in this research refers to Pintrich (1995) that there is an active effort from students by directing goals, self and behaviour control, motivation, and cognition in completing individual assignments.

This research uses self-regulated learning dimensions based on components from (Pintrich, Smith, Garcia \& McKeachie, 1991). They are value, expectation, sentiment cognitive and metacognitive strategies, resources management strategy. effort regulation.

\section{Goal Setting}

Goal setting is the simplest introspective observation by showing awareness, individual strength, particular directed behaviour, dan purposeful (Locke \& Latham, 1990; Ryan, 1970; Zimmerman, 2002). In classroom teaching, goal setting is defined as a process to build learning direction, which is clarified as learning motivation and to improve academic achievement (Marzano, Pickering \& Pollock, 2001; Schunk, 2009; Rowe, Mazzoti, Ingram \& Lee, 2017).

There are two dimensions of goal setting i.e. content and intensity that are used in this article: Content and Intensity (Lee, Locke \& Latham, 1989; Locke \& Latham, 1990; Locke \& Latham, 1990)

\section{Self-efficacy}

Self-efficacy is a belief to one's ability to successfully accomplish something (Bandura, 1994). Meanwhile, Zimmerman (2003); Pintrich dan De Groot (1990) defined selfefficacy as related to academic development in the form of perception and utilization of selfregulation strategy to student's ability to accomplish clear and useful academic goals. (Bandura,1997; Fenollar, Roman \& Cuestas, 2007; Zajacova, Lynch, \& Espenshade, 2005; Solberg et al, 1993).

Self-efficacy dimensions are based on research from Solberg \& friends (Solberg, O’Brien, Villarreal, Kennell, \& Davis, 1993) in college i.e. course efficacy, roommate efficacy, and social efficacy.

\section{Interest}

Interest is defined as positive and balanced feeling refers to attraction, favorite, desire or want (Valsiner, 1992). Among educational research, interest is considered as great curiosity (Ainley, 1987) or to like planned learning 
(Renninger et al, 2004; Krapp, Renninger \& Hoffman, 1998).

According to Hidi (2006) and Renninger (2006), interest is defined as psychological condition as characteristic of affective component such as positive emotion and cognitive component such as concentration. (Hidi \& Renninger, 2006), which contains and motivated by experience. Interest is the center of intrinsic motivation, a form of independence of extrinsic motivation (Deci, 1992; Ryan \& Connel, 1989), and an extreme form of experience of interest called flow (Csikszentmihalyi, 1975; Schiefele, 1991; Durik \& Harackiewicz, 2007)

There are three dimensions of interest i.e. feeling related valences, value related valences, and intrinsic orientation (Schiefele, 1983; Prenzel, 1988; Berlyne, 1960; Alport, 1961; Dewey, 1913; Rathunde \& Csikszentmihalyi, 1993).

\section{Peer Support}

Peer support is a system that enables individuals to give and receive help, based on the principle of appreciation, sharing responsibility, and mutual agreement about the help. Peer support involves empathy understanding through emotional sharing experiences and psychological issues (Shery Mead, David Hilton, \& Lourie Curtis, 2000; Dennis, 2003).

According to Cohen and Huberman (1983), peer support is support given to peers in the form of financial or material support, social support in the form of ownership support, selfesteem support, and appraisal support. (Cohen, 2004; Santrock, 2007) Dimensions of peer support consists of four dimensions (Cohen \& Hoberman, 1983) i.e. tangible, belonging, appraisal and self-esteem.

\section{Research Hypothesis}

Major Hypothesis: There are significant influences from goal setting (content, intensity), self-efficacy (course efficacy, roommate efficacy, social efficacy), interests (affected related valence, value related valence, intrinsic orientation), peer support (tangible, belonging, appraisal, selfesteem) towards self-regulated learning.

Minor Hypothesis: 1) Content has an impact on goal setting on self-regulated learning; 2) Intensity has an impact on goal setting on self-regulated learning; 3) Course effect has an impact on self-efficacy on self-regulated learning; 4) Roommate efficacy has an impact self-efficacy on self-regulated learning; 5) Social efficacy has an impact on self-efficacy on self-regulated learning; 6) Affected related valence has an impact on interest on self-regulated learning; 7) Value of valence has an impact on interest on self-regulated learning; 8) Intrinsic orientation has an impact on interest on self-regulated learning; 9) Tangible has an impact on peer support on self-regulated learning; 10) Belonging has an impact on peer support on self-regulated learning; 11) Appraisal has an impact on peer support on self-regulated learning; 12) Selfesteem has an impact on peer support on selfregulated learning.

\section{Methods}

The research population is 328 students of National Crypto Institute (Sekolah Tinggi Sandi Negara - STSN) ranging from first year to fourth year of education year 2018 - 2019. Questionnaires were distributed by author via Google Forms in collaboration with the Department of Technology and Student Affairs of STSN.

Sampling technique used in this research is non probability sampling, with convenience sampling technique. This is a non-probability sampling where sampling is taken based on the 
elements availability and gathering convenience. Samples were taken or selected because the samples were in the right place and time. This sampling technique is suitable for research with focused group (Shaughnessy, 2012).

Motivated Strategies for Learning Questionnaire (MSLQ) scale by (Pintrich et al., 1991) were used as measuring instrument for self-regulated learning. Pintrich and colleagues consists of self-report with 81 items based on motivational components (Pintrich, 2003; Wingfield \& Eccles, 2000), and learning strategies in particular training or lessons, which consists of value components, expectation components, sentiment components, cognitive and metacognitive strategies, resources management strategy.

Goal setting questionnaire is used as goal setting measuring instrument, which refers to of Locke \& Latham (1990), consists of 2 dimensions i.e. content and intensity. Each content consists of factors: specificity, proximility; difficulty; and meaningful. There are 19 total items.

College self-efficacy inventory (CSEI) from Solberg, O'Brien, Villarreal, Kennel, \& Davis, (1993) is used as self-efficacy measuring instrument. This instrument contains 20 questions that measure believe and confidence level of students to show their performance in college. This instrument relates to three dimensions, self-efficacy to tasks (7 items), social self-efficacy (9 items), and roommate selfefficacy (4 items). The instrument uses uses a 4point Likert scale from scale 1 (very insecure) to scale 4 (very confident).

Interest measuring instrument used Study Interest Questionnaire (SIQ) scale which was introduced by Winteler \& Schiefele (1987) and has been revised twice by Winteler, Sierwald \& U. Schiefele, 1988. This measuring instrument of interest was made to apply the concept of interest, as a subject assessment in college (Schiefele, Krap, Wild \& Winteler, 1993). The instrument uses a 4-point Likert scale from scale 1 (very compatible) to scale 4 (very incompatible) with total of 17 items.

Research on peer support used The Interpersonal Support Evaluation List (ISEL) (Cohen \& Hoberman, 1983), a multidimensional inventory measuring instrument that measures social perception support. The author used this inventory because ISEL uses students as population research. This inventory contains 4 subscales i.e. (1) appraisal, valuable perceptions of others to offer advice, cognitive guidance and information, 2). tangible, in the form of assistance, material or instrumental support, 3). Self-esteem, in the form of social comparison, and 4). belonging, refers to valuable perceptions for others and friendship. The instrument uses a 4-point Likert scale from scale 1 (very compatible) to scale 4 (very incompatible).

\section{Results and Discussion}

Table 1. Analysis Summary Model Regression

\begin{tabular}{|c|c|c|c|c|c|c|c|c|c|}
\hline \multicolumn{10}{|c|}{ Model Summary' } \\
\hline \multirow[t]{2}{*}{ Model } & $R$ & $R$ & Adjusted & Std. Error of & & Chang & Statis & & \\
\hline & & & R Square & the Estumate & $\begin{array}{c}R \\
\text { Square } \\
\text { Change }\end{array}$ & $\stackrel{\text { F }}{\text { Chrnge }}$ & dfl & $d 2$ & $\begin{array}{l}\text { Sig. } P \\
\text { Chrange }\end{array}$ \\
\hline 1 & $.720^{4}$ & 0.518 & 0.497 & 7.09015 & 0.518 & 24907 & 12 & 278 & 0 \\
\hline
\end{tabular}

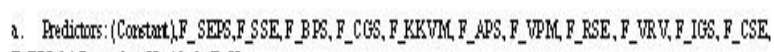

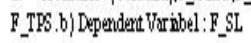

Table 1 shows that obtained value of $\mathrm{R} 2$ is 0.518 or $51.8 \%$. This means that proportion variance of self-regulated learning, which is explained by all independent variables (content, intensity, course efficacy, roommate efficacy, social efficacy, affected related valence, value related valence, intrinsic orientation, tangible, belonging, appraisal, self-esteem) in this research is $51.8 \%$, while the other $48.2 \%$ is affected by 
other variables outside this research. Next, the author analyzed the impact of all independent variables on self-regulated learning. F test result can be seen in table 2 .

Table 2. Anova Effect of all IV towards DV

\begin{tabular}{|c|c|c|c|c|c|c|}
\hline \multicolumn{7}{|c|}{ ANONA $^{2}$} \\
\hline Model & & Sum of Squares & Df & Mean Square & F & Sig. \\
\hline \multirow[t]{3}{*}{1} & Regression & 15024.86 & 12 & 1252.072 & 24.907 & $.000^{5}$ \\
\hline & Residual & 13975.14 & 278 & 50.27 & & \\
\hline & Total & 29000 & 290 & & & \\
\hline
\end{tabular}

a. Dependent Variable: F_SRL

b. Predictors: (Constant), F_ SEPS,F_SSE, F_BPS, F_CGS, F_KKVM, F_APS, F_VPM, F_RSE , F_VRV, F_IGS, F_CSE, F_TPS. b) Dependent Variable : F_SL

Table 3. The Regression Equation

\begin{tabular}{|c|c|c|c|c|c|c|}
\hline \multicolumn{7}{|c|}{ Coefficients $\mathrm{s}^{2}$} \\
\hline \multirow[t]{2}{*}{ Model } & & \multicolumn{2}{|c|}{$\begin{array}{l}\text { Unstandar dized } \\
\text { Coefficients }\end{array}$} & \multirow{2}{*}{$\begin{array}{l}\text { Standardized } \\
\text { Coefficients } \\
\text { Beta }\end{array}$} & \multirow[t]{2}{*}{$\mathrm{t}$} & \multirow[t]{2}{*}{ Sig. } \\
\hline & & B & Std Error & & & \\
\hline & (Constant) & 14.629 & 4.124 & & 3.547 & 0 \\
\hline \multirow{12}{*}{1} & Content & 0.052 & 0.069 & 0.052 & 0.759 & 0.449 \\
\hline & Intensity & 0.195 & 0.072 & 0.195 & 2.722 & $0.007 *$ \\
\hline & Course Efficacy & 0.271 & 0.072 & 0.271 & 3.78 & $0.000 *$ \\
\hline & Roommate Efficacy & 0.077 & 0.067 & 0.077 & 1.151 & 0.251 \\
\hline & Social Efficacy & -0.053 & 0.078 & -0.053 & -0.681 & 0.496 \\
\hline & $\begin{array}{l}\text { Afected Related } \\
\text { Valence }\end{array}$ & 0.098 & 0.066 & 0.098 & 1.483 & 0.139 \\
\hline & $\begin{array}{l}\text { Value Related } \\
\text { Valence }\end{array}$ & 0.092 & 0.071 & 0.092 & 1.294 & 0.197 \\
\hline & Intrinsic Orientation & 0.164 & 0.072 & 0.164 & 2.267 & $0.024 *$ \\
\hline & Tangible & -0.025 & 0.074 & -0.025 & -0.335 & 0.738 \\
\hline & Belonging & -0.05 & 0.073 & -0.05 & -0.688 & 0.492 \\
\hline & Appraisal & -0.076 & 0.067 & -0.076 & -1.142 & 0.254 \\
\hline & Self-esteem & -0.038 & 0.043 & -0.038 & -0.899 & 0.369 \\
\hline
\end{tabular}

Self-regulated learning $=+14,629+0.052$ (Content) +0.195 (Intensity) +0.271 (Course Efficacy) +0.077 (Roommate Efficacy) -0.053 (Social Efficacy) + 0.098 (Affected Related Valence) + 0.092 (Value Related Valence) + 0.164 (Intrinsic Orientation) - 0.025 (Tangible) - 0.05 (Belonging) - 0.076 (Appraisal) - 0.038 (Self-esteem).

From the regression equation above, it appeared that from 12 independent variables, there are 3 significant variables which are intensity, course efficacy, and intrinsic orientation. Explanation of the regression coefficient values obtained for each independent variable is as follows: 1) Content: obtained from regression coefficient of 0.052 with Sig of 0.448
(Sig> 0.05), thus null hypothesis which states that there is no significant effect of content on self-regulated learning is accepted. This means that content does not have a significant effect on self-regulated learning; 2) Intensity: obtained from regression coefficient of 0.195 with Sig of 0.007 (Sig <0.05), thus null hypothesis which states there is no significant effect of intensity on self-regulated learning is rejected. The results above show that the intensity has a significant positive effect. This means that the higher the intensity the higher self-regulated learning and conversely the lower the intensity the lower the self-regulated learning; 3) Course Efficacy: obtained from regression coefficient of 0.271 with Sig of 0.000 (Sig <0.05), thus null hypothesis which states there is no significant effect of course efficacy on self-regulated learning is rejected. The results above show that course efficacy has a significant positive effect. This means that the higher the course efficacy, the higher self-regulated learning, and conversely, the lower the course efficacy the lower the selfregulated learning; 4) Roommate Self-efficacy: obtained from the regression coefficient of 0.077 with Sig of 0.251 (Sig> 0.05), thus null hypothesis which states that there is no significant effect of roommate self-efficacy on self-regulated learning is accepted. This means that roommate self-efficacy doesn't have a significant effect on self-regulated learning; 5) Social Efficacy: obtained from regression coefficient of - 0.053 with Sig of 0.496 (Sig> 0.05), thus null hypothesis which states that there is no significant effect of social efficacy on self-regulated learning is accepted. This means that social efficacy doesn't have a significant effect on self-regulated learning; 6) Affected Related Valence: obtained from regression coefficient of 0.098 with Sig of 0.139 (Sig> 0.05), thus null hypothesis which states that there is no significant effect of affected related valence on self-regulated learning is accepted. This means that affected related valence does not 
have a significant effect on self-regulated learning; 7) Value Related Valence: obtained from regression coefficient of 0.092 with Sig of 0.197 (Sig> 0.05), thus null hypothesis which states that there is no significant effect of Value Related Valence on self-regulated learning is accepted. This means that Value Related Valence does not have a significant effect on selfregulated learning; 8) Intrinsic Orientation: obtained from regression coefficient of 0.164 with Sig of 0.024 (Sig <0.05), thus null hypothesis which states there is no significant effect of the Intrinsic Orientation on selfregulated learning is rejected. This means that Intrinsic Orientation has a significant positive effect on self-regulated learning. The higher the Intrinsic Orientation the higher the selfregulated learning, and conversely the lower the Intrinsic Orientation the lower the self-regulated learning; 9) Tangible: obtained from regression coefficient of -0.025 with Sig of 0.738 (Sig> $0.05)$, thus null hypothesis which states that there is no significant effect of Tangible on selfregulated learning is accepted. This means that Tangible does not have a significant effect on self-regulated learning; 10) Belonging: obtained from regression coefficient of -0.05 with Sig of 0.492 (Sig> 0.05), thus null hypothesis which states that there is no significant effect of Belonging on self-regulated learning is accepted. This means Belonging does not have a significant effect on self-regulated learning; 11) Appraisal: obtained from regression coefficient of -0.076 with Sig of 0.254 (Sig> 0.05), thus a null hypothesis which states that there is no significant effect of Appraisal on selfregulated learning is accepted. This means that Appraisal does not have a significant effect on self-regulated learning; 12) Self-esteem: obtained from regression coefficient of -0.038 with Sig of 0.369 (Sig> 0.05), thus null hypothesis which states that there is no significant effect of Self-esteem on self-regulated learning is accepted. This means that Self-esteem does not have a significant effect on selfregulated learning.

Based on the hypothesis test result above, it can be concluded that there are only 3 of 12 variables that have a significant impact on selfregulated learning. They are the intensity, course efficacy, and intrinsic orientation.

To determine which predictor among each independent variable has the greatest impact on dependent variable can be seen through column standardized coefficient beta in Table 3 regression coefficient. Regardless of the positive or negative, independent variable with the largest beta coefficient can be concluded as a predictor that has the greatest impact on dependent variable.

Based on the beta coefficient, independent variable with the biggest predictor of selfregulated learning is the variable of course selfefficacy, which equals to $\beta=0.271$.

Table 4. Proportion Summary Model on Each IV towards DV

\begin{tabular}{|c|c|c|c|c|c|c|c|c|c|}
\hline \multicolumn{10}{|c|}{ Model Summary } \\
\hline \multirow[t]{2}{*}{ Model } & \multirow[t]{2}{*}{$\mathrm{R}$} & \multirow{2}{*}{$\begin{array}{c}R \\
\text { Square }\end{array}$} & \multirow{2}{*}{$\begin{array}{l}\text { Adjustes } \\
\text { R. Square }\end{array}$} & \multirow{2}{*}{$\begin{array}{l}\text { Sid. Erro } \\
\text { of the } \\
\text { Estimute }\end{array}$} & \multicolumn{5}{|c|}{ Chenge S tatititics } \\
\hline & & & & & $\begin{array}{l}\text { R. Squ xe } \\
\text { Change }\end{array}$ & $\stackrel{F}{\text { F }}$ & df 1 & $\mathrm{~d} 2$ & $\begin{array}{l}\text { Sig. F } \\
\text { Change }\end{array}$ \\
\hline 1 & .422 & 0.178 & 0175 & 9.08163 & $0.17 \xi$ & 62.617 & 1 & 299 & 0 \\
\hline 2 & .488 & $0.2: 8$ & 0.233 & $\varepsilon .76052$ & 0.06 & 22.574 & 1 & 288 & 0 \\
\hline 3 & .647 & 0.418 & $0.4: 2$ & 7.66876 & 0.18 & 3884 & 1 & 287 & 0 \\
\hline 4 & .650 & $0.4: 3$ & $04: 5$ & 3.64988 & 0.005 & 2.418 & 1 & 286 & 0.121 \\
\hline 5 & .650 & $0.4 \div 3$ & $04: 3$ & 7.66321 & 0 & 2.005 & 1 & 285 & 0.942 \\
\hline 5 & .686 & C.47 & 0.459 & 7.35651 & 0.047 & 2526 & 1 & 244 & 0 \\
\hline 7 & .698 & 0.457 & 0474 & 7.25071 & 0.017 & 9.348 & 1 & 283 & 0.002 \\
\hline 3 & .06 & 0.458 & 0.484 & 7.18196 & 0.011 & 5.44 & 1 & 282 & 0.012 \\
\hline 9 & .715 & 0.511 & 0.495 & 3.10439 & 0.019 & 7.9: & 1 & 281 & 0.008 \\
\hline 10 & .717 & 0.514 & 0497 & 7.0954 & 0.009 & 1.713 & 1 & 280 & 0.192 \\
\hline 11 & $\therefore 19$ & 0.517 & 0.498 & 7.08773 & 0.00 & 1.606 & 1 & 279 & 0.206 \\
\hline 12 & .320 & 0.518 & 0497 & 3.09015 & 0.001 & 2.809 & 1 & 278 & 0.369 \\
\hline
\end{tabular}

Model Summary: Model R: R Square Adjusted R Square Std. Error of the Estimate Change Statistics

Based on Table 4, it can be concluded as follows: 1) Content: variable contributed $17.8 \%$ to the variance of self-regulated learning. The variance is significant, with $\mathrm{F}$ change $=62,617$, $\mathrm{df} 1=1$ and $\mathrm{df} 2=289$ with Sig. $\mathrm{F}$ change $=$ 0,000 (Sig F change <0.05); 2) Intensity: 
variable contributed $6 \%$ to the variance of selfregulated learning. The variance is significant, with $\mathrm{F}$ change $=22,574, \mathrm{df}=1$ and $\mathrm{df} 2=288$ with Sig F change $=0,000$ (Sig F change $<0.05$ ); 3) Course Efficacy: variable contributed $18 \%$ to the variance of self-regulated learning. The variance is significant, with $\mathrm{F}$ change $=88.84, \mathrm{df}$ $=1$ and $\mathrm{df} 2=287$ with Sig F change $=0.000$ (Sig F change <0.05); 4) Roommate Efficacy: variable contributed $0.5 \%$ to the variance of selfregulated learning. The variance is not significant, with $\mathrm{F}$ change $=2,418, \mathrm{df}=1$ and df $2=286$ with Sig F change $=0.121($ Sig F change> 0.05); 5) Social Efficacy: variable contributed $0 \%$ to the variance of self-regulated learning. The variance is not significant, with $\mathrm{F}$ change $=0.005, \mathrm{df}=1$ and $\mathrm{df} 2=285$ with Sig F change $=0.942 \quad($ Sig $F$ change $>0.05)$; 6) Affected Related Valence: variable contributed $4.7 \%$ to the variance of selfregulated learning. The variance is significant, with $\mathrm{F}$ change $=25.26, \mathrm{df}=1$ and $\mathrm{df} 2=284$ with Sig F change $=0.000$ (Sig F change $<0.05$ ); 7) Value Related Valence: variable contributed $1.7 \%$ to the variance of self-regulated learning. The variance is significant, with $\mathrm{F}$ change = 9,348, df $=1$ and df2 $=283$ with Sig F change = 0.002 (Sig F change <0.05); 8) Intrinsic Orientation: variable contributed $1.1 \%$ to the variance of self-regulated learning. The variance is significant, with $\mathrm{F}$ change $=6,444, \mathrm{df}=1$ and $\mathrm{df} 2=282$ with $\mathrm{Sig} F$ change $=0.012(\mathrm{Sig} F$ change $<0.05)$; 9)Tangible: variables contributed $1.3 \%$ to the variance of selfregulated learning. The variance is significant, with $\mathrm{F}$ change $=7,191, \mathrm{df}=1$ and $\mathrm{df} 2=281$ with Sig F change $=0.008$ (Sig F change $<0.05$ ); 10) Belonging: variable contributed $0.3 \%$ to the variance of self-regulated learning. The variance is not significant, with $\mathrm{F}$ change $=1,713, \mathrm{df}=1$ and df2 $=280$ with Sig F change $=0.192($ Sig F change 0.05$)$; 11) Appraisal: variable contributed $0.3 \%$ to the variance of selfregulated learning. The variance is not significant, with $\mathrm{F}$ change $=1,606, \mathrm{df}=1$ and $\mathrm{df} 2=279$ with Sig F change $=0.206($ Sig F change> 0.05); 12) Self-esteem: variable contributed $0.1 \%$ to the variance of selfregulated learning. The variance is significant, with $\mathrm{F}$ change $=0.809, \mathrm{df}=1$ and $\mathrm{df} 2=278$ with Sig F change $=0.369$ (Sig F change $>0.05)$.

Based on the explanation above, it can be concluded that there are 7 variables that contribute significantly to the variance of selfregulated learning based on the amount of R2 produced. The 7 predictors are content, intensity, course efficacy, affected related valence, value related valence, intrinsic orientation, tangible.

\section{Discussion}

Course efficacy variable has significant impact and contributes to self-regulated learning by $18 \%$. This research result supports the statement of Corno (1993), Kuhl (1984), Zimmerman (1998), Pajares and Schunk, (2001) that course efficacy impacts the process of selfregulated learning in increasing student confidence and ability to complete college assignments, as well as performance and perseverance for better learning.

Students who can regulate themselves well, will effectively regulate their thoughts, motivation, and behaviour in order to achieve learning goals and success (Bandura, 1986; Pintrich, 1995, 2004; Philip H Winne, 2010; Zimmerman, 2002). Their activities are to direct, modify, and maintain expected result which includes the ability to follow instructions, process and knowledge integration, practicing information memorization, as an assurance to their learning ability and to anticipate the result (Schunk, 1986).

The next variable, goal setting is intensity. Intensity has impact and contributes to selfregulated learning by $6 \%$. This finding 
corroborates the research of Lee, Locke and Latham, (1989); and Locke and Latham (1990) that intensity impacts self-regulated learning, through individual commitment to control cognitive, sentiment and actions in the form of tasks completion. Likewise, intensity is done by setting and working on goals that must be completed in a short time and meaningful.

Intrinsic orientation variable, significantly impacts and contributes to self-regulated learning by $1.1 \%$. The results of this study corroborate the statement of Rathunde and Csikszentmihalyi (1993), that interest which originates from intrinsic orientation increases the activity of attachment to assignments through a combination of emotional characteristics and orientation components of personal values. This combination arises when there is incentive from oneself or others in the form of appreciation, satisfaction, and happiness during the learning process.

Peer support variables (tangible, belonging, appraisal, self-esteem) do not have a significant effect on self-regulated learning, but still have a contribution although not as large as intensity, course efficacy and intrinsic orientation variables. Tangible (1.3\%), belonging $(0.3 \%)$, appraisal $(0.3 \%)$, and self-esteem $(0.1 \%)$. This finding contradicts the research of Brar, Ryu, Shaikh, Altman, Jeremy (2012), Liamas and Sanchez Ramos (2013), Stracke and Kumar (2014), and Hafzan, Nasirah, Norida, Kalthom (2015), which states that peer support has a significant effect on self-regulated learning.

\section{Conclusions}

There is a significant impact from content, intensity, course efficacy, roommate efficacy, social efficacy, affected related valence, value related valence, intrinsic orientation, tangible, belonging, appraisal, and self-esteem altogether towards self-regulated learning. There are three variables of 12 variables that have a significant impact on self-regulated learning i.e. goal setting (intensity), self-efficacy (course efficacy), and interest (intrinsic orientation). The most dominant variable which impacts self-regulated learning $(\mathrm{DV})$ is course efficacy with beta value = 0.271 .

For further research on self-regulated learning, it is suggested to: 1) Take independent variables that also affect self-regulated learning such as character building, interpersonal interaction, positive psychology, self-value, environmental, community psychology, boarding schools at the university level, and samples of universities with different cultural or ethnic backgrounds; 2) Research result showed the value of R2 $51.8 \%$ tends to be large, this happens: a) possibly because there are many strong theories, so the regression model can properly explain the data according to hypothesized; b) There was a serious violation of the regression assumptions and a violation of 3 requirements of good independent variable; 3) This research was conducted with boarding students as sample, so character building is an important part that needs to be instilled to students, and further research will be more interesting if the process of character building can be carried out using self-regulated learning strategies, in which there are cognitive, motivational, and behavioral control processes. for practical suggested to: 1) Conduct seminars on socialization to students and lecturers about the description and influencing factors; 2) Provide workshops on effective learning techniques and strategies, phases in self-regulated learning (planning phase by analyzing perceptions of prior learning, monitoring metacognitive awareness, controlling actions goals that have and have not been done, making evaluation materials, and track record of student learning processes), the meaning and benefits of self-regulated learning itself; 3) Provide training 
to lecturers, about building effective learning communities, in the form of effective teaching methods, which can maximize cognitive strategies function such as elaboration, organization and critical thinking. Connect lessons with various fields of study or other work, in innovative and meaningful way. Provide challenging tasks with certain difficulty level, but with clear deadlines and specification of expected results; 4) Conduct regular workshops on time management strategies, and maximize the role of mentoring and study groups on a regular basis. Create a control and evaluation book to identify which learning that has been understood, as track record of the learning process, and control different stages; 5) Make outbound and inbound activities to improve peer support quality among students related to self-regulated learning such as teamwork to overcome group problems, working together to make resumes and mind maps on the material, role playing, group project based on going cases, debate match about values, character and ethics problems faced by students; 6) Create discussion and sharing forum about the meaning and benefits of peers towards the learning process, conducted in the foster family community or group mentor. Maximizing student senate functions to facilitate students to get to know better the characteristics of roommates and classmates; 7) Conduct effective communication training or "jouhari windows", about self-values, interests, preferences and hopes with roommates, classmates, and all students, as well as competitions involving synergy with roommates; 8) Make regular programs (posters, jargon, group activities) to students and lecturers about internalization of STSN values, which can increase collective efficacy, the true spirit of the solidarity in learning activities and development of student self-identity (character quality improvement), in order to have better group confidence.

\section{References}

Ainley, (1987). The factor structure of curiosity measures:breadth and depth of interest curiosity styles. Australian journal of psychology 39(1); 53-59.

Allgood, W.P, Risko, V.J, Álvarez, M.C, \& Fairb. (2000). Factors that influence study. In R.F. Flippo , \& D.C. Caverly , Handbook of college reading and study strategy research (pp. 201-219). New York: NJ: LEA.

Alport, G. W. (1961). Pattern and growth in personality. New York: Holt.

Balapumi, Aitken, \& Ashley. (2012). Concepts and factors influencing independent learning in is higher education. Proceedings of the 23rd Australasian Conference on Information Systems (ACIS) (pp. 1-10). Geelong, Victoria: Deakin University.

Bandura, A. (1986). Social foundations of thought and action: A social cognitive theory. Neywork: Englewood Cliffs, NJ: Prentice-Hall.

Bandura, A. (1997). Self-efficacy: The exercise of control. New York: Freeman.

Bandura. (1994). "Self-efficacy", In V. S. Ramachaudran (Ed.), In Bandura, Encyclopedia of human behavior (Vol. 4, pp. 71-81). New York: Academic Press.

Behaghely. (2015). Ready for boarding? the effects of boarding school for disadvantaged students. American Economic Journal: Applied Economics, 9(1), 140-164.

Bembenuty, H. (2011). Introduction: Selfregulation of learning in postsecondary education. New directions for teaching and learning. Journal online Willey, 126, 3-8. 
Berlyne, D. E. (1960). McGraw-Hill series in psychology. Conflict, arousal, and curiosity. New York, NY, US: McGrawHill Book Company.

BR Lee \& Barth. (2009). Residential education: An emerging resource for improving educational outcomes for youth in foster care? Children \& Youth Services Review, 31, 155-160.

Cohen, S. (2004). Social Relationships and Health. American Psychologist, 59(8), 676-684.

Cohen, S., \& Hoberman, H. (1983). Positive events and social supports as buffers of life change stress. Journal of Applied Social Psychology, 13, 99-125

Cookson, P. W. (2009). Perspectives on elite boarding schools. In M. Berends, M. G. Springer, D. Ballou, \& H. J. Walb, Handbook of research on school choice (pp. 461-478). New York: Oxon: Routledge.

Cree, A. C. (2000). Lights out and be quiet! A sociological research in Australian boarding education (2nd ed.). Parkville, Australia: Australian Combined University Press.

Csikszentmihalyi, M. (1975). Beyond Boredom and Anxiety. Washington: Jossey-Bass Publishers.

Csikszentmihalyi, M., Rathunde, K., \& Whalen, S. (1993). Talented teenagers. New York, NY: Cambridge University Press.

Deci, E.L. (1992). The relation of interest to the motivation of behavior: a selfdetermination theory perspective. In K.A. Renninger, S. Hidi \& A. Krapp (Eds.), The role of interest in learning and development. Hillsdale, NJ: Erlbaum, pp. 43-71.
Dennis, (2003) Peer support; Concept analysis; Theory development; Nursing science. International Journal of Nursing Studies 40 (2003) 321-332.

Dewey, J. (1913). Interest and effort in education. Boston: Riverside Press.

Durik, A. M., \& Harackiewicz, J. M. (2007). Different strokes for different folks: How individual interest moderates the effects of situational factors on task interest. Journal of Educational Psychology, 99(3), 597610.

Fenollar, Roman \& Cuestas, (2007). University students' academic performance: an integrative conceptual framework and empirical analysis. British Journal of Educational Psychology 77 (4):873-891.

Hidi, S. (2006). Interest: A unique motivational variable. Educational Research Review, 1, 69-82.

Hidi, S., \& Renninger, K. A. (2006). The fourphase model of interest development. Educational Psychologist, 41, 111-127.

Krapp, Renninger \& Hoffman, (1998). Interest, learning, and the psychological processes that mediate their relationship. Journal of educational psychology, 94(3).545-561

Lee, T. W., Locke, E. A. \& Latham, G. P. (1989). Goal setting theory and job performance. In L. A. Pervin (Ed.), Goat Concepts in Pmonatity and Social Psychology. Hillsdale, NJ: Erlbaum

Lieberman, D. A., \& Remedios, R. (2007). Do undergraduates' motives for studying change as they progress through their degrees? British Journal of Educational Psychology, 77(2), 379-395.

Locke, E. A. \& Latham, G. P. (1990). A Theory of Goal Setting and Task Performance. Englewood Cliffs NTPrentice-Hall. 
Marzano, R., Pickering, D., \& Pollock, J. (2001). Classroom instruction that works. Association for Supervision and Curriculum Development. Alexandria, VA

McCombs, B. L. (1989). Self-regulated learning and academic achievement. A phenomenological view. In B. J. Zimmerman \& D. H. Schunk (Eds.), Selfregulated learning and academic achievement: Theory, research, and practice (pp. 51-82). New York: Springer.

Perven. S. \& Kazmi, F.S., (2011). Personality dynamics of boarders and day scholars who belong to madrassah and public school. Journal Academic Research International.

Pintrich, (1995), Understanding self-regulated learning. New directions for teaching and learning, University of Michigan, Ann Arbor.

Pintrich, (2004). Conceptual framework for assesing motivation, Semantic Scholar. Educational Psychology Review, 16 (4).

Pintrich, P. R., \& Zusho, A. (2002). The development of academic self-regulation: The role of cognitive and motivational factors. In A. Wigfield \& J.S. Eccles (Eds.), Development of achievement motivation (pp. 249-284). San Diego, $\mathrm{CA}$ : Academic.

Pintrich, P.R., \& DeGroot, E. (1990). Motivational and self-regulated learning components of classroom academic performance. Journal of Educational Psychology, 82, 33-40.

Pintrich, P.R., Cross, D.R., Kozma, R.B., \& McKeachie, w.J. (1986). Instructional psychology. Annual Review of Psychology, 37, 611-651.

Pintrich, Smith, Garcia, McKeachie (1991). A Manual for the use of the motivated strategies for learning questionnaire. Suite
2400 School of Education Building the University of Michigan.

Prenzel, M. (1988). Die Wirkungswei se von Interesse. Ein Erkldrungsversuch aus padagogisch-Opladen, Germany: Westdeutscher Verlag.

Prenzel. M. (1992). Selective persistence of interest. In K. A. Renninger, S. Hidi, \& A. Krapp (Eds.), The role of interest in learning and development (pp. 7198). Hillsdale, NJ.: Erlbaum.

Ratnaningsih, S., Nahartini, D., Yuliyani, A. (2018). The Effect of Problem Based Learning Methods and Self Confidence to English Learning Outcomes in the Elementary School. TARBIYA: Journal of Education in Muslim Society, 5(2), 135144. doi:10.15408/tjems.v5i2.10640.

Renninger, K. A., Sansone, C., \& Smith, J. L. (2004). Love of learning. In C. Peterson \& M. E. P. Seligman (Eds.), Character strengths and virtues: A classification and handbook (pp. 161-179). New York: Oxford University Press.

Rosario, P.,Mourao, R.Nunez.,J.,GonazalezPienda,J.,Solano,P.,\& Valle, A. (2007). Evaluating the efficacy of a program to enhance college student's self-regulation learning processes and learning strategies. Psicothema, 19,422-427.

Rosfiani, O., Akbar, M., Neolaka, A. (2019). Assessing Student Social Studies Learning: Effects of Learning Environment, Inquiry, and Student Learning Interest. TARBIYA: Journal of Education in Muslim Society, 6(1), 46-57. doi:10.15408/tjems.v6i1.11593.

Rowe, Mazzoti, Ingram, Lee (2017). Effect of goal setting instruction on academic engagement for students at risk. Career Development and Transition for 
Exceptional Individuals 2017, 40(1) 25 35.

Ryan \& Connel, (1989). A motivational analysis of self-determination and self-regulation in education. Research gate. 13-51

Ryan, T. A. (1970). Intentional Behavior. New York: Ronald Press.

Santrock, J.W. (2007) Child development. 11th Edition, McGraw-Hill,

Schiefele, (1991). Interest, learning and motivation. Journal Educational Psychologist 26 (3).299-323

Schiefele, M. Prenzel, A. Krapp, (1983). Principles of an educational theory of interest, Presented at the 7th Biennial Meeting of the international society for the stdy of behavioral development, Munich, West Germany

Schunk, D. (2009). Goal setting. Retrieved from education.com:

http://www.education.com/reference/articl e/goalsetting/

Schunk, D. H. (1986). Verbalization and children's self-regulated learning. Contemporary Educational Psychology, 11, 347-369.

Schunk, D.H., \& Zimmerman, B.J. (2003). Social origins of self-regulatory competence. Educational Psychologist, 32 , 195-208.

Shaughnessy, John J., (2012). Research methods in psychology.9th ed. The McGraw-Hill Companies. Newyork.

Shery Mead, David Hilton, \& Lourie Curtis, (2000). Peer support: A theoretical perspective. Psychiatric rehabilitation journal 25(2): 134-141.
Solberg, V. S., O’Brien, K., Villareal, P., Kennel, R., \& Davis, B. (1993). Self-efficacy and Hispanic college students: Validation of the college self-efficacy instrument. Hispanic Journal of Behavioral Sciences, 15(1), 80-95.

Stewart, M., Stott, T., \& Nuttall, A.-M. (2015). Study goals and procrastination tendencies at different stages of the undergraduate degree. Studies in Higher Education, 1-16.

Tuckman, B.W. (2003). The effect of learning and motivation strategies training on college students' achievement. Journal of College Student Development, 44, 430437.

Valsiner, (1992). Interest:A meta theoretical perspective. In K.A. Renninger,S.Hidi, \& A. Krapp (eds). The role of interest in learning and development (pp.27-41). Hillsdale, NJ:Erlbaum

Weinstein, C., and Mayer, R. (1986). The teaching of learning strategies. In Wittrock, M. (ed.), Handbook of Research on Teaching and Learning, Macmillan, New York, pp. 315- 327.

Williams,R. (2011). The socialization of the power elite in an American boarding school (Unpublished senior thesis). Haveford College, Haverford, PA.

Winne PH, (2010). The psychology of academic achievement. Annual review of psychology 61, 653-678.

Zajacova, Lynch, \& Espenshade, (2005). Selfefficacy, stress, and academic success in college. Research in higher education, 46(6) 677-706

Zimmerman BJ. (2002) Becoming a selfregulated learner: an overview. Theory into Practice.; 41(2):64-70. 
Zimmerman, B. J. (1994). Dimensions of academic self-regulation: A conceptual framework for education. In D. H. Schunk \& B. J. Zimmerman (Eds.), Selfregulation of learning and performance: Issues and educational applications (pp. 321). Hillsdale, NJ: Erlbaum.

Zimmerman, B. J., and Martinez-Pons, M. (1986). Development of a structured interview for assessing student use of selfregulated learning strategies. Am. Educ. Res. J. 23: 614-628.
Zirima, H. (2012). Double Jeprardy: The Psycho-educational effects of absent parenting on children with spesific learning disabilities. Florida: BocaRaton. 